CARPATHIAN JOURNAL OF FOOD SCIENCE AND TECHNOLOGY

Journal home page: http://chimie-biologie.ubm.ro/carpathian_journal/index.html

\title{
EFFECT OF THERMAL PROCESSING AND FERMENTATION ON THE CHEMICAL COMPOSITION, PROTEIN DIGESTIBILITY AND FUNCTIONAL PROPERTIES OF BAMBARA PROTEIN ISOLATE
}

\begin{tabular}{|c|c|}
\hline \multicolumn{2}{|c|}{ 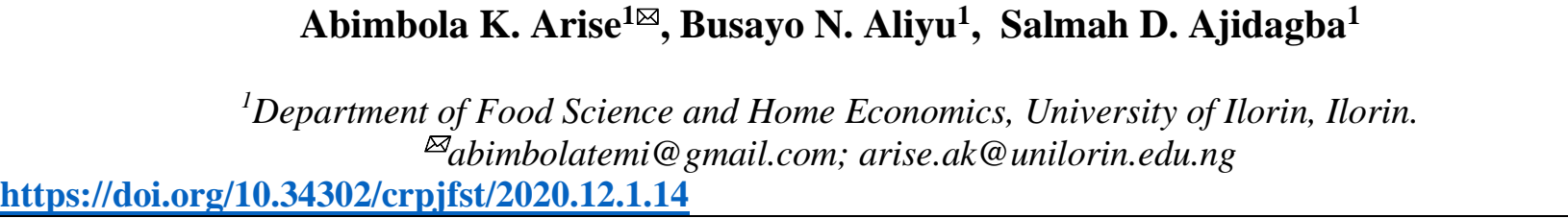 } \\
\hline Article history: & Abstract \\
\hline $\begin{array}{l}\text { Received: } \\
\text { 28 January } 2019 \\
\text { Accepted: } \\
15 \text { January } 2020 \\
\end{array}$ & $\begin{array}{l}\text { Protein isolate offers huge opportunity in the expansion of a new class of } \\
\text { formulated foods. In this study, the effect of thermal processing and } \\
\text { fermentation on the chemical composition, protein digestibility and } \\
\text { functional properties of Bambara nut protein isolate were investigated. }\end{array}$ \\
\hline $\begin{array}{l}\text { Keywords: } \\
\text { Bambara nut; } \\
\text { Fermentation; } \\
\text { Boiling; } \\
\text { Roasting; } \\
\text { Protein digestibility. }\end{array}$ & $\begin{array}{l}\text { Thermal processing reduced the yield of the protein }(53.4 \% \text { and } 51.6 \%) \\
\text { while fermentation increased the yield of the protein }(54 \%) \text { when compared } \\
\text { to the raw sample }(53.8 \%) \text {. Protein digestibility of the isolate significantly } \\
\text { increased due to thermal processing and fermentation. The proximate } \\
\text { composition of the isolate revealed that fermentation increased the crude } \\
\text { protein content of protein isolate }(83.2 \%) \text { compared to the raw sample } \\
(82.3 \%) \text { while all the processing method used increased the ash content } \\
\text { significantly. Processing had no effect on the water absorption capacity, } \\
\text { foaming capacity and stability of the protein isolate. However, the emulsion } \\
\text { stability of all the samples improved with processing. Protein digestibility, } \\
\text { yield, protein content, and emulsion stability were improved by processing } \\
\text { especially fermentation, these attributes may improve the possible use of } \\
\text { Bambara nut protein isolates as an excellent protein ingredient in the food } \\
\text { system. }\end{array}$ \\
\hline
\end{tabular}

\section{Introduction}

The emphasis of our research recently has been on the use of vegetable proteins for the formulation of new food products and functional foods. This is because animal protein is still luxurious in developing countries than plant protein (Arise et al., 2015). However, in order to advance in the use of vegetable proteins for food ingredients, their physicochemical and functional properties must be assessed. Many legumes consumed in Africa are important sources of nutrients, especially proteins and a good source of complex carbohydrates as reported by many studies which makes them a perfect food to combat malnutrition (Ogodo et al., 2017).

Bambara groundnut (Vigna subterranean (L.) Verdc.) is a native of African legume that has been cultivated in Africa for periods. It originated from the Sahelian region which is the present-day West Africa with its name comes from the Bambara tribe who lives in Mali (Boateng et al., 2013). In Africa, Bambara has been classified as the third most significant legume after groundnut (Arachis hypogea) and Cowpea (Vigna ugniculata) (Adebowale et al., 2007, Arise et al., 2015). The protein content of Bambara groundnut varies between 15-27\% (Arise et al., 2015, Murevanhema and Jideani, 2013).It is interesting to note that Bambara seed grain contains a good balance of essential amino acid with a relatively high proportion of lysine (6.5-6.8\%) and a considerable amount of methionine which is unusual in other legumes (Arise et al., 2017). A major attribute of Bambara groundnut is its forbearance to drought, poor soils and ability to yield in conditions where other legumes fail entirely. 
It can moderately resist pest and disease, this gives it a greater advantage over soybean and groundnut (Mazahib et al., 2013). Processing through heat application and fermentation has been stated to reduce the antinutritional influences and toxic contents in nuts and legumes thereby exposing the seed to utilization (Arinola and Adesina, 2014, Iyenegbe et al., 2017). Roasting, apart from lowering the antinutrients, has also been found to improve the palatability and nutrients of food products thereby increasing shelf life. The chemical composition, as well as functional properties of cashew nut, were stated to have been enhanced by processing methods (Fagbemi et al., 2006). Protein extracts have superior functions and are more successfully used in the formulation of foods compared to cereal flour (Boye et al., 2010). Protein isolate offers enormous opportunity in the development of a new class of formulated foods. The high concentration of protein results in colour, flavour and functional properties of greater value which makes protein isolates an ideal raw material for use in beverages, infants \& children milk food, textured protein products and certain types of specialty foods (Boye et al., 2010).Therefore, the aim of this study is to investigate the effect of thermal processing and fermentation on the protein digestibility, chemical and functional properties of the protein isolates.

\section{Materials and methods}

\subsection{Materials}

Bambara groundnut was obtained from OjaOba market in Ilorin. The seeds were screened to remove defective seeds. Other materials include; bowls, weighing scale, polythene bags, electric oven, autoclave, and milling machine. All apparatus, chemical, and equipment used were obtained from the food processing laboratory in the department of Home Economics and Food Science, University of Ilorin. The nuts were washed to remove dirt, dehulled and divided into four parts. A part was boiled at $100^{\circ} \mathrm{C}$ for 30 minutes, another portion was roasted at $120^{\circ} \mathrm{C}$ for 45 minutes and the third part was fermented in water for 4 days at room temperature while the fourth part was used in the raw form. The de-hulled seed was milled into flour using hammer mill and then sieved through a $0.4 \mathrm{~mm}$ mesh size, packaged in highdensity polyethylene bag and stored in a refrigerator at $4^{\circ} \mathrm{C}$ till further used.

\subsection{Preparation of defatted Bambara nut flour and protein isolates}

The various samples of Bambara nut were defatted using the method of Arise et al. (2015). Briefly, Bambara seed flours were each defatted with n-hexane in the ratio 1:5 (flour: solvent) for 3 hours. Defatted flours were placed in a fume hood overnight to remove the remaining hexane. The fat content was less than $0.01 \%$ after defatting using the soxhlet extractor. Protein content $(\mathrm{N} \times 6.25)$ of the defatted flours was determined using the Kjedahl method (AOAC, 2012). Protein isolates were prepared from the defatted flour samples using isoelectric precipitation method as described by Arise et al. (2015) with slight modification. Precisely, the defatted flour was mixed with distilled water $(1: 10 \mathrm{w} / \mathrm{v})$ and the $\mathrm{pH}$ of the mixture was adjusted to 9.0 with $1 \mathrm{M} \mathrm{NaOH}$ so as to facilitate protein solubilization. The suspension was stirred for $4 \mathrm{~h}$ at $32{ }^{\circ} \mathrm{C}$ in a shaking water bath. Centrifugation was thereafter carried out. The centrifuge was set at $4000 \mathrm{~g}$ for $30 \mathrm{~min}$ at $4{ }^{\circ} \mathrm{C}$. After centrifugation and recovery of the supernatant, the precipitate was resuspended in half the volume of initial water and extraction was carried out as described above. The supernatants were pooled together and $\mathrm{pH}$ adjusted to 4.0 with $0.5 \mathrm{M}$ HCL to precipitate the protein concentrates, which were recovered by centrifugation at $5000 \mathrm{~g}$ for $30 \mathrm{~min}$ at $4{ }^{\circ} \mathrm{C}$. The precipitated protein was washed in three volumes of distilled water and neutralized to $\mathrm{pH}$ 7 with $1 \mathrm{M} \mathrm{NaOH}$. The neutralized protein isolate was freeze-dried, the resulting powder was held in a tight container and stored at $4{ }^{\circ} \mathrm{C}$ for further analysis.

\subsection{Proximate composition of the isolates}

Moisture, fat, ash and protein contents were determined using AOAC methods (AOAC, 2012). The micro kjeldahl nitrogen method was used in the determination of the crude protein 
content. A conversion factor of 6.25 was used to convert the nitrogen content to protein. The carbohydrate content was determined by difference (100-[moisture + total ash + crude fat + crude fibre + protein $])$.

\subsection{Protein yield}

The yield of protein concentrate was determined as the dry weight of protein concentrate after precipitation and solubilization respectively per weight of the defatted flour as shown below (Arise et al., 2015)

Yield

protein concentrate recovery $X$ protein content of concentrate $(\%) \times 100$ Protein content of defatted flour (\%)

(Eq.1)

\subsection{Determination of the in-vitro Protein Digestibility}

In-vitro protein digestibility was carried out by the method of Chavan et al. (2001). A known weight sample containing 16 mg nitrogen was taken in triplicate and hydrolysed with $1 \mathrm{mg}$ pepsin in $15 \mathrm{ml}$ of $10 \%$ (w/v) trichloroacetic acid (TCA). The mixture was then filtered quantitatively through Whatman No. 1 filter paper. The TCA soluble fraction was assayed for nitrogen micro-Kjedahl method. Digestibility was calculated using the following formula:

$$
\begin{aligned}
& \text { Protein digestibility } \%= \\
& \qquad \frac{(N \text { in supernatant }-N \text { in blank })}{N \text { in sample }} \times 100
\end{aligned}
$$

\subsection{Colour parameters}

Colour of Bambara protein isolates were measured at room temperature using a Chroma Meter CR-400 (Minolta Co. LTD. Japan). Colour analysis was done by putting the device on the freeze-drying Bambara protein isolate at least in triplicates. Colour of isolate was measured as the average of 3 readings for each sample after calibrating the instrument. Colour was measured as lightness $\left(\mathrm{L}^{*}\right)$, redness $\left(\mathrm{a}^{*}\right)$, and yellowness $\left(b^{*}\right)$. Whiteness was calculated by the equations: $L^{*}-3 b$ as referred by Codex Alimentarius

\subsection{Functional properties}

\subsubsection{Water and Oil absorption capacity}

The water absorption capacity (WAC) and oil absorption capacity (OAC) were determined as described by Arise et al. (2015). Briefly, sample $(1.0 \mathrm{~g})$ was weighed into a $15 \mathrm{ml}$ preweighed centrifuge tube to which $10 \mathrm{ml}$ of distilled water (for WAC) or $10 \mathrm{ml}$ of soybean oil (for OAC) was added stepwise with continuous stirring at room temperature for 10 min. The suspension in the tube was centrifuged at $2,500 \times g$ for $20 \mathrm{~min}$ and the volume of supernatant measured. The WAC or OAC was calculated as the difference between the initial volume of water or oil used and the final volume of the decanted supernatant and calculated in percentages, taking into consideration the density of the oil.

\subsubsection{Least gelation concentration}

The least gelation concentration (LGC) was determined according to the method described by Abbey and Ibeh (1988). The sample was weighed and mixed with $5 \mathrm{ml}$ of distilled water in a test tube to obtain 2\%-20\% (w/v) concentrations. The test tube was heated for $1 \mathrm{hr}$. in a boiling water bath followed by rapid cooling under running tap water and further cooled for 2 $\mathrm{hr}$. in a refrigerator at $4{ }^{\circ} \mathrm{C}$. The LGC was regarded as the least concentration at which the sample from the inverted tube did not fall or slip.

\subsubsection{Foaming Capacity and Stability}

Foaming capacity (FC) and foaming stability (FS) were carried out as described by Arise et al., (2015). The sample (0.5 g) was dispersed in $50 \mathrm{ml}$ of distilled water in a $100 \mathrm{ml}$ graduated cylinder and the solutions homogenized at a speed of $1,600 \times g$ for $5 \mathrm{~min}$. The volume was recorded before and after whipping. FC was expressed as the volume (\%) increase due to whipping. This was then stored for $1 \mathrm{hr}$ and the foam- volume changes in the graduated cylinder were recorded as FS.

Foaming capacity $=$

$\frac{\text { Volume after homogenization-Volume before homogenization }}{\text { Volume before homogenization }} X 100$ 


\subsubsection{Emulsion capacity (EC) and Stability}

This was determined according to the method of Chavan et al. (2001). One gram of the sample in $25 \mathrm{ml}$ distilled water was homogenized at a speed of 5,000 $\times \mathrm{g}$ for $1 \mathrm{~min}$ at $27{ }^{\circ} \mathrm{C}$. The protein solution was then mixed with $25 \mathrm{ml}$ of soybean oil followed by homogenization at $10,000 \times g$ for $1 \mathrm{~min}$. The emulsion volume was then used in calculating the EC as shown below:

Emulsifying capacity $(\%) \quad=$ $\frac{\text { Height of emulsified layer in the tube }}{\text { Height of the total content in the tube }} \times 100$

The emulsion stability (ES) was measured by re-centrifugation as above and heating for 30 min at $80^{\circ} \mathrm{C}$. The ES was calculated as shown below

Emulsifying stability $(\%)$
$\frac{\text { Height of remaining emulsion layer }}{\text { Height of initial emulsion layer }} \times 100$

\subsection{Statistical analysis}

Statistical analysis Experiments were conducted in triplicate. Mean scores of some of the results and their standard deviation were reported. Data were subjected to analysis of variances, and Duncan multiple range test was used to separate the means (Duncan, 1955)

\section{Results and discussion}

\subsection{Protein yield of the isolates}

Protein yield of Bambara protein isolate ranges from 51.60 to $54.00 \%$ (table 1). The protein yield of the isolates obtained in this research is in agreement with the result obtained by Arise et al. (2015) which ranges from 49.50 to $54.50 \%$. However, the result obtained is higher than $27.05-29.41 \%$ reported for two Bambara nut landraces by Boateng et al. (2013). High protein yield and content gotten in this study may be attributed to adjustment in $\mathrm{pH}$ using $\mathrm{NaOH}$ ( $\mathrm{pH}$ 9.5), which may enhance extraction. Protein has been stated to display higher solubility at $\mathrm{pH}$ above their isoelectric point (Adebowale et al., 2007). This study shows that the processing method increased the yield of the Bambara nut protein isolate. The yield of the fermented and roasted sample increased compared to the raw isolate while the yield of the boiled sample reduced. The low yield recorded in the boiled sample may be due to leaching of some soluble components in water coupled with denaturation by heat.

Table 1. Protein yield of the isolates

\begin{tabular}{|l|l|}
\hline Sample & Protein Yield (\%) \\
\hline Raw & $53.8^{\mathrm{b}} \pm 0.1$ \\
\hline Roasted & $53.4^{\mathrm{b}} \pm 0.4$ \\
\hline Fermented & $54.0^{\mathrm{c}} \pm 0.1$ \\
\hline Boiled & $51.6^{\mathrm{a}} \pm 0.3$ \\
\hline
\end{tabular}

Values with similar superscripts in a column do not differ significantly $(\mathrm{P}<0.05)$.

Table 2. Proximate Composition of Raw and Processed Bambara Groundnut Protein isolate

\begin{tabular}{|l|l|l|l|l|l|l|}
\hline Samples & $\begin{array}{c}\text { Crude } \\
\text { protein } \\
(\boldsymbol{\%})\end{array}$ & $\begin{array}{c}\text { Moisture } \\
\text { content }(\boldsymbol{\%})\end{array}$ & $\begin{array}{c}\text { Ash } \\
\text { Content } \\
(\boldsymbol{\%})\end{array}$ & Fat $(\boldsymbol{\%})$ & $\begin{array}{c}\text { Crude } \\
\text { fibre } \\
(\boldsymbol{\%})\end{array}$ & $\begin{array}{c}\text { Carbohydrate } \\
(\boldsymbol{\%})\end{array}$ \\
\hline Raw & $82.3^{\mathrm{c}} \pm 2.0$ & $3.2^{\mathrm{b}} \pm 0.0$ & $3.0^{\mathrm{a}} \pm 0.1$ & $0.0^{\mathrm{a}} \pm 0.0$ & $0.0^{\mathrm{a}} \pm 0.0$ & $11.5^{\mathrm{b}} \pm 0.0$ \\
\hline Fermented & $83.2^{\mathrm{d}} \pm 0.8$ & $3.2^{\mathrm{b}} \pm 0.0$ & $4.7^{\mathrm{d}} \pm 0.1$ & $0.0^{\mathrm{a}} \pm 0.0$ & $0.0^{\mathrm{a}} \pm 0.0$ & $8.9^{\mathrm{a}} \pm 0.0$ \\
\hline Roasted & $80.4^{\mathrm{a}} \pm 1.2$ & $3.0^{\mathrm{a}} \pm 0.0$ & $4.5^{\mathrm{c}} \pm 0.2$ & $0.0^{\mathrm{a}} \pm 0.0$ & $0.0^{\mathrm{a}} \pm 0.0$ & $12.1^{\mathrm{b}} \pm 0.0$ \\
\hline Boiled & $81.3^{\mathrm{b}} \pm 0.5$ & $3.5^{\mathrm{c}} \pm 0.0$ & $3.8^{\mathrm{b}} \pm 0.2$ & $0.0^{\mathrm{a}} \pm 0.0$ & $0.0^{\mathrm{a}} \pm 0.0$ & $11.4^{\mathrm{b}} \pm 0.0$ \\
\hline
\end{tabular}

Values with similar superscripts in a column do not differ significantly $(\mathrm{P}<0.05)$. 


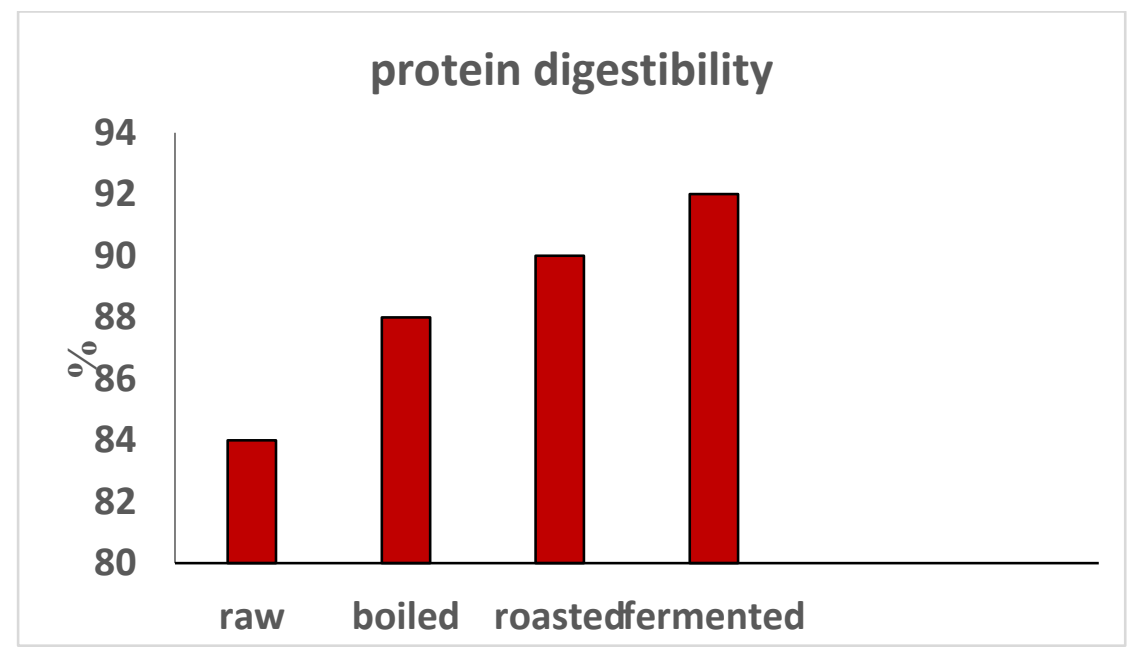

Figure 1. In-vitro protein digestibility of Bambara groundnut protein isolate

\subsection{Proximate composition of the protein isolates}

The effect of processing (boiling, roasting, and fermentation) on the proximate composition of Bambara groundnut protein isolate on a dry weight basis are presented in table 2 . The result revealed that boiling, roasting, and fermentation significantly affect the crude proteins, ash and moisture content. The samples had high protein content ranging from 80 to $83 \%$. These values were lower compared to the $86 \%$ protein reported by Eltayeb et al. (2011) and higher than the $80 \%$ reported by Gbadamosi et al. (2012). The result for the protein content of all protein isolates was consistent with criteria for legume protein isolates, in which protein must be higher than 70\% (Butt and Batool, 2010). The high protein content recorded can be considered for protein supplements in human. There was a significant difference among the samples in ash content. The protein isolates contained ash content that ranges from 3 to $5 \%$. It can be inferred from this result that ash content reduces on soaking/steeping in water as in the case of fermented isolate and increases due to the application of heat, which come to an agreement with the findings of Abdulsalami and Sheriff (2010), for Bambara groundnut seeds. Processing had no significant effect on the crude fiber, fat and carbohydrate content of the isolate.
This result is in line with what was reported by Iyenagbe et al. (2017) for boiled and roasted conophor nuts.

\subsection{In-vitro protein digestibility of the isolates}

The effect of fermentation and thermal processing on the percentage in-vitro protein digestibility of the Bambara groundnut protein isolate samples is shown in figure 1. The values range from 84 to $92 \%$, this shows that processing of Bambara nut protein isolate enhances its digestibility. All processing methods used, led to an increase in the digestibility of protein. However, among the three samples, the fermented sample gave the uppermost value of $92 \%$ while the boiled sample gave the lowest. The changes in the in-vitro protein digestibility differ significantly $(p<0.05)$ in the processed sample compared to the raw sample. The increase in protein digestibility compares favorably with the finding of Ogodo et al. (2017), especially for the fermented sample. This author reported that fermentation increased protein digestibility from $68.70 \%$ to $85.24 \%$. Improvements in the protein digestibility of the protein isolates may be due to the modifications that occur in protein during $n$ atural fermentation. 
Table 3. Colour parameter of Bambara groundnut Protein isolate

\begin{tabular}{|c|c|c|c|}
\hline Samples & $\mathrm{L}^{*}$ & $\mathrm{a}^{*}$ & $\mathrm{~b}^{*}$ \\
\hline Raw & $65.8^{\mathrm{ab}} \pm 2.3$ & $8.4^{\mathrm{b}} \pm 0.3$ & $6.3^{\mathrm{ab}} \pm 0.3$ \\
\hline Fermented & $71.5^{\mathrm{a}} \pm 4.4$ & $7.9^{\mathrm{b}} \pm 0.5$ & $7.4^{\mathrm{b}} \pm 0.7$ \\
\hline Roasted & $57.3^{\mathrm{c}} \pm 6.2$ & $10.1^{\mathrm{a}} \pm 0.5$ & $6.3^{\mathrm{ab}} \pm 1.6$ \\
\hline Boiled & $62.2^{\mathrm{bc}} \pm 2.3$ & $8.1^{\mathrm{b}} \pm 0.2$ & $5.0^{\mathrm{a}} \pm 0.7$ \\
\hline
\end{tabular}

Mean \pm SD. Mean with different superscript along the column are significantly different $(p<0.05)$

\subsection{Colour parameters}

The effect of thermal processing and fermentation on the colour parameters of Bambara protein isolate are presented in table 3. All colour data were expressed by hunter 1 , a and $\mathrm{b}$ values corresponding to lightness, redness, and yellowness respectively. The colour of the Bambara protein isolate was significantly affected by the processing method employed. The roasted sample seemed slightly brown in colour with low lightness $\left(1^{*}\right)$, high redness $\left(\mathrm{a}^{*}\right)$ and yellowness $\left(b^{*}\right)$ values, the other boiled and fermented sample have a brighter colour with increased lightness $\left(1^{*}\right)$, low redness $\left(a^{*}\right)$ and yellowness $\left(b^{*}\right)$. This result agrees with the findings of Nikmaram et al. (2011) who worked on the effect of cooking methods on veal muscle. The study revealed that roasting reduced brightness and increased redness on the surface of the meat due to the formation of dark pigments while boiling improved the brightness.

\subsection{The water absorption capacity of Bambara protein isolate}

The values gotten for the WAC of the raw, roasted, fermented, and boiled Bambara nuts protein isolates are $218.50 \%, 159.00 \%$, $135.50 \%$, and $185.50 \%$ respectively as shown in table 4. The raw sample gave the highest WAC which implies that pre-treating the samples had no effect on the WAC of the protein isolates. The value obtained in this study for WAC for the raw Bambara nuts protein isolate are higher than $205.22 \%$ for peanuts protein isolate by Sibt-eAbbas et al. (2015), 174.65\% for Bambara protein isolate by Adeleke et al. (2018) but similar to $221.83 \%$ reported for Bambara protein isolate by Eltayeb et al. (2011). The higher WAC of raw Bambara protein isolate may be due to the higher polar amino acid residues of Bambara proteins having an affinity for water molecules. A high WAC was observed in the fermented sample of protein isolates which may be attributed to the water binding sites on the side chain groups of protein units (Adebowale et al., 2007). The increased WAC in fermented sample suggests their use in aqueous food formulations especially those involving dough formation like bread and cookies (Adebowale et al., 2011).

\subsection{The oil absorption capacity of Bambara protein isolate}

The OAC of the raw, roasted, fermented and boiled is $56.00 \%, 72.00 \%, 72.00 \%$ and $95.50 \%$ respectively (table 4). The protein-protein interaction could have been aided by the high protein content in the concentrate which could be responsible for the increase in OAC of the isolates. All the processing methods used in this study increased the OAC with the boiled sample having the highest OAC while roasted and fermented samples have the same oil absorption capacity. Oil absorption capacity is an essential parameter since oil increase the mouth feel of food and act as flavour retainer in certain food products. Although the values for OAC obtained in this study are lower compared to $100.67 \%$ obtained from peanuts (Sibt-e-Abbas et al., 2015), the Bambara protein isolate still has the possibility of been used as an ingredient in piefilling, meat extenders and meat substitutes for sausages. 
Table 4. Functional properties of processed Bambara nuts protein isolates

\begin{tabular}{|l|l|l|l|l|}
\hline Samples & Raw & Roasted & Fermented & Boiled \\
\hline WAC \% & $218.50 \pm 2.1^{\mathrm{a}}$ & $159.00 \pm 1.4^{\mathrm{a}}$ & $135.50 \pm 0.9^{\mathrm{a}}$ & $185.50 \pm 0.5^{\mathrm{a}}$ \\
\hline OAC \% & $56.00 \pm 0.9^{\mathrm{c}}$ & $72.00 \pm 2.83^{\mathrm{b}}$ & $72.00 \pm 0.0^{\mathrm{c}}$ & $95.50 \pm 0.7^{\mathrm{b}}$ \\
\hline FC \% & $15.00 \pm 0.0^{\mathrm{d}}$ & $5.00 \pm 0.0^{\mathrm{f}}$ & $10.00 \pm 0.0^{\mathrm{e}}$ & $10.00 \pm 0.0^{\mathrm{e}}$ \\
\hline EC \% & $15.00 \pm 0.0^{\mathrm{d}}$ & $15.00 \pm 0.0^{\mathrm{d}}$ & $16.50 \pm 0.7^{\mathrm{d}}$ & $14.00 \pm 0.0^{\mathrm{d}}$ \\
\hline ES \% & $5.50 \pm 0.7^{\mathrm{b}}$ & $7.50 .00 \pm 0.7^{\mathrm{e}}$ & $8.00 \pm 0.00^{\mathrm{f}}$ & $6.50 \pm 0.7^{\mathrm{f}}$ \\
\hline LGC \% & $62.00 \pm 0.0^{\mathrm{b}}$ & $42.00 \pm 0.0^{\mathrm{c}}$ & $83.00 \pm 0.0^{\mathrm{b}}$ & $42.00 \pm 0.0^{\mathrm{c}}$ \\
\hline
\end{tabular}

In each of the rows, any means not followed by the same superscripts are significantly different $(p<0.05>)$ Sample Keys: WAC: Water absorption capacity, OAC: Oil absorption capacity ,FC: Foaming capacity EC: Emulsion capacity, ES: emulsion stability, LGC: Least gelation concentration

\subsection{Foaming capacity and foaming stability}

Foam is a colloid of many gas foams trapped in a liquid or solid. Small air bubbles are surrounded by thin liquid films. Foam can be produced by whipping air into a liquid as much and as fast as possible (Sikorski, 2006). The values obtained for $\mathrm{FC}$ of the isolates ranged from $5.00 \%$ to $15.00 \%$. The values obtained are low and are not improved with processing, this may be due to the pre-treatment (roasted, boiled, fermented) which may have destroyed the structure of the protein preventing it from forming a cohesive visco-elastic film, or it may have been from the preparations of the samples. There was no foam stability observed after 10 mins. This indicates that the pre-treated Bambara protein isolate has very poor foaming capacity and stability.

\subsection{Emulsion capacity and stability}

Emulsion capacities of the raw, roasted, fermented and boiled are $15.00 \%, 15.00 \%$, $16.50 \%$ and $14.00 \%$ respectively, Whereas the values for emulsion stability of the protein isolates are $5.50 \%, 7.50 \%, 8.00 \%$, and $6.50 \%$ respectively. The protein isolates emulsion capacity and stability were significantly increased by roasting and fermentation. A similar observation was observed for conophor nut protein isolates (Iyenagbe, et al., 2017). The emulsion capacity and stability observed in this study points out that it can be used as an ingredient in mayonnaise and sausage in the food industry.

\subsection{Least gelation concentration}

The values obtained for LGC in this study are in the ranges of $42.00 \%-83.00 \%$ as shown in table 4 below. The roasted and boiled samples have the lowest LGC for the protein isolate. With these results, it shows that Bambara nut protein isolate may not be a good gelling agent when compared to soybean protein isolates (Padilla et al., 1996) and hemp protein isolate (Malomo et al., 2015). However, the protein gel texture can be improved by the addition of non - protein component. For instance, an improvement in protein gel texture was also reported when carbohydrates were added (Adebowale et al., 2007).

\section{Conclusions}

The results obtained from this research shows that fermentation is the most suitable processing method. The fermented sample gave the highest yield for protein isolate, also in terms of the nutritional composition of the isolate, the fermented sample had the highest protein and ash content. Furthermore, in terms of functional properties, the fermented sample had a better emulsion capacity and stability. Generally, thermal processing and fermentation resulted in an increase in the digestibility of the protein isolate. Therefore, we can conclude that raw Bambara nut should undergo fermentation before protein isolation for use in the food industry. 


\section{References}

Abbey, B. W. \& Ibeh, G. (1988). Functional properties of raw and heat processed cowpea (Vigna unguiculata, Walp) flour. Journal of Food Science, 53, 1775-1777.

Abdulsalami, M. \& Sheriff, H. (2010). Effect of processing on the proximate composition and mineral content of bambara groundnut (Voandezeia subterranean). Bayero Journal of Pure and Applied Sciences, 3 (1), 188190.

Adebowale, Y. A., Adeyemi, I. A., Oshodi, A. A. \& Niranjan, K. (2007). Isolation, fractionation and characterisation of proteins from Mucuna bean. Food Chemistry, 104, 287-299.

Adebowale, Y. A., Schwarzenbolz, U. \& Henle, T. (2011). Protein isolates from Bambara groundnut (Voandzeia Subterranean L.): Chemical characterization and functional properties. International Journal of Food Properties, 14, 758-775.

Adeleke, O. R., Adiamo, O. Q. \& Fawale, O. S. (2018). Nutritional, physicochemical, and functional properties of protein concentrate and isolate of newly-developed Bambara groundnut (Vigna subterrenea L.) cultivars. Food Science \& Nutrition, 6, 229-242.

AOAC (2012). Official methods of analysis of AOAC International (19th ed.), Gaithersburg, M.D USA.

Arinola, S. O. \& Adesina, K. (2014). Effect of thermal processing on the nutritional, antinutritional, and antioxidant properties of Tetracarpidium conophorum (African Walnut). Journal of Food Processing, 1, 14.

Arise, A. K., Alashi, A. M., Nwachukwu, I. D., Malomo, S. A., Aluko, R. E. \& Amonsou, E. O. (2017). Inhibitory properties of bambara groundnut protein hydrolysate and peptide fractions against angiotensin-converting enzymes, renin and free radicals. Journal of the Science of Food and Agriculture, 97, 2834-2841.

Arise, A. K., Amonsou, E. O. \& Ijabadeniyi, O. A. (2015). Influence of extraction methods on functional properties of protein concentrates prepared from South African bambara groundnut landraces. International Journal of Food Science \& Technology, 50, 1095-1101.

Boateng, M., Addo, J., Okyere, H., AduDapaah, H., Berchie, J. \& Tetteh, A. (2013). Physicochemical and functional properties of proteinates of two bambara groundnut (Vigna substerran) landraces. African Journal of Food Science and Technology, 4, 64-70.

Boye, J., Zare, F. \& Pletch, A. (2010). Pulse proteins: Processing, characterization, functional properties and applications in food and feed. Food research international, 43, 414-431.

Butt, M. S. \& Batool, R. (2010). Nutritional and functional properties of some promising legumes protein isolates. Pakistan Journal of Nutrition, 9, 373-379.

Chavan, U., Mckenzie, D. \& Shahidi, F. (2001). Functional properties of protein isolates from beach pea (Lathyrus maritimus L.). Food Chemistry, 74, 177-187.

Duncan, D. B. (1955). Multiple range and multiple F tests. Biometrics, 11, 1-42.

Eltayeb, A. R. S., Ali, A. O., Abou-Arab, A. A. \& Abu-Salem, F. M. (2011). Chemical composition and functional properties of flour and protein isolate extracted from Bambara groundnut (Vigna subterranean). African Journal of Food Science, 5, 82-90.

Fagbemi, T., Oshodi, A. \& Ipinmoroti, K. (2006). Effects of processing on the functional properties of full fat and defatted fluted pumpkin (Telfairia occidentalis) seed flours. Journal of Food Technology, 4, 7079.

Gbadamosi, S. O., Abiose, S. H. \& Aluko, R. E. (2012). Amino acid profile, protein digestibility, thermal and functional properties of Conophor nut (Tetracarpidium conophorum) defatted flour, protein concentrate and isolates. International Journal of Food Science \& Technology, 47, 731-739.

Iyenagbe, D. O., Malomo, S. A., Idowu, A. O., Badejo, A. A. \& Fagbemi, T. N. (2017). Effects of thermal processing on the nutritional and functional properties of 
defatted conophor nut (Tetracarpidium conophorum) flour and protein isolates. Food Science \& Nutrition, 5, 1170-1178.

Malomo, S. A., Onuh, J. O., Girgih, A. T. \& Aluko, R. E. (2015). Structural and antihypertensive properties of enzymatic hemp seed protein hydrolysates. Nutrients, 7, 7616-7632.

Mazahib, A., Nuha, M., Salawa, I. \& Babiker, E. (2013). Some nutritional attributes of bambara groundnut as influenced by domestic processing. International Food Research Journal, 20, 1165-1171

Murevanhema, Y. Y. \& Jideani, V. A. (2013). Potential of Bambara groundnut (Vigna subterranea (L.) Verdc) milk as a probiotic beverage-A review. Critical Reviews in Food Science and Nutrition, 53, 954-967.

Nikmaram, P., Yarmand, M. S., Emamjomeh, Z. \& Darehabi, H. K. (2011). The effect of cooking methods on textural and microstructure properties of veal muscle (Longissimus dorsi). Global Veterinaria, 6, 201-207.

Ogodo, A. C., Ugbogu, O. C., Onyeagba, R. A. \& Okereke, H. C. (2017). Effect of Lactic Acid Bacteria Consortium Fermentation on the Proximate Composition and in-Vitro Starch/Protein Digestibility of Maize. American Journal of Microbiology and Biotechnology, 4, 35-43.

Omowaye-Taiwo, O. A., Fagbemi, T. N., Ogunbusola, E. M. \& Badejo, A. A. (2015). Effect of germination and fermentation on the proximate composition and functional properties of full-fat and defatted cucumeropsis mannii seed flours. Journal of Food Science and Technology, 52, 52575263.

Padilla, F., Alvarez, M. \& Alfaro, M. (1996). Functional properties of barinas nut flour (Caryodendron orinocense Karst., Euphorbiaceae) compared to those of soybean. Food Chemistry, 57, 191-196.

Sibt-E-Abbas, M., Butt, M., Sultan, M., Sharif, M., Ahmad, A. \& Batool, R. (2015).
Nutritional and functional properties of protein isolates extracted from defatted peanut flour. International Food Research Journal, 22, 1533-1537.

Sikorski, Z. E. (2006). Chemical and functional properties of food components, CRC press.

Sze-Tao, K. W. C. \& Sathe, S. K. (2000). Walnuts (Juglans regia L): proximate composition, protein solubility, protein amino acid composition and protein in vitro digestibility. Journal of the Science of Food and Agriculture, 80, 1393-1401.

Wani, I. A., Sogi, D. S., Shivhare, U. S. \& Gill, B. S. (2015). Physico-chemical and functional properties of native and hydrolyzed kidney bean (Phaseolus vulgaris L.) protein isolates. Food research international, 76, 11-18. 